\title{
ANALISIS FAKTOR RISIKO KEJADIAN HUMAN IMMUNODEFICIENCY VIRUS (HIV) PADA LELAKI SEKS LELAKI (LSL)
}

\author{
Bunga Tiara Carolin ${ }^{1}$, Suprihatin², Aprinda Maharani P.K ${ }^{3}$ \\ 1Program Studi Kebidanan, Fakultas IImu Kesehatan, Universitas Nasional Jakarta \\ Email: bungacarolinmbmd@gmail.com \\ 2Program Studi Kebidanan, Fakultas IImu Kesehatan, Universitas Nasional Jakarta \\ Email: atin_bio@yahoo.com \\ ${ }^{3}$ Program Studi Kebidanan, Fakultas IImu Kesehatan, Universitas Nasional Jakarta \\ Email: dindamaharanikesuma@ymail.com
}

\begin{abstract}
Background: The HIV \& AIDS virus is increasing rapidly like a time bomb for the world and is becoming an epidemic. Based on UNAIDS data, there are 1.8 million sufferers in various countries. Asia Pacific ranks third as the region with the most HIV and AIDS sufferers worldwide with a total of 5.2 million people, Indonesia accounts for 620,000 of the total 5.2 million people infected with HIV / AIDS.

Purpose: To analyze the risk factors associated with the incidence of HIV among male homosexual in Pasar Tengah Hotspot Bandar Lampung City in 2019.

Methods: Analytical research is cross sectional approach. The sampling technique is Random sampling technique, with 84 respondents. The research instrument used questionnaire sheets that had been tested for validity and reliability. Data analysis used Chi Square $\left(X^{2}\right)$ test.

Results: Univariate results found that 26.2\% were infected with HIV, 53.6\% used condoms, had a history of sexual infectious disease was $26.3 \%, 37.7 \%$ was high-risk sexual behavior, and no one used injecting drugs. Bivariate results showed condom use $(p=0.001)$, history of sexual infectious disease $(p=1,000)$, risky sexual behavior $(p=0.002)$, and injecting drug use $(p=0.569)$.

Conclusions: There a significant relationship between condom use and risky sexual behavior and the incidence of HIV among male homosexual. While the history of sexual infectious disease, and injecting drug use do not have a significant relationship with HIV incidence among male homo sexual.

Suggestion: Male Homosexual are expected to be able to improve the consistency of condom and lubricant use, whether used for themselves or their partners or customers, always routinely do VCT tests and are not lazy or even shy to check for health services, also contribute actively in preventing HIV \& AIDS transmission.
\end{abstract}

Keywords: Risk Factors, HIV\&AIDS, Male Homosexual.

\section{ABSTRAK}

Latar belakang: Virus HIV\&AIDS meningkat dengan pesat seperti bom waktu bagi dunia dan menjadi epidemik. Berdasarkan data UNAIDS, penderita yang ada di berbagai negara sebanyak 1,8 juta. Asia Pasifik menduduki peringkat ketiga sebagai wilayah dengan pengidap HIV dan AIDS terbanyak diseluruh dunia dengan total penderita sebanyak 5,2 juta jiwa, Indonesia menyumbang angka 620.000 dari total 5,2 juta jiwa terjangkit HIVIAIDS.

Tujuan: Penelitian ini untuk menganalisis faktor-faktor risiko yang berhubungan dengan kejadian HIV pada LSL di hotspot pasar tengah Kota Bandar Lampung tahun 2019.

Metode: Penelitian analitik dengan pendekatan cross sectional. Teknik pengambilan sampel random sampling, dengan 84 responden. Instrument penelitian menggunakan lembar kuisioner yang sudah diuji validitas dan reliabilitas. Analisis data menggunakan uji Chi Square $\left(X^{2}\right)$.

Hasil: Hasil univariat didapatkan $26,2 \%$ terinfeksi HIV, 53,6\% menggunakan kondom, pernah mengalami riwayat IMS $26,3 \%, 37,7 \%$ perilaku seks berisiko tinggi, dan tidak ada yang menggunakan narkoba suntik. Hasil bivariat didapatkan penggunaan kondom $(p=0,001)$, riwayat IMS $(p=1,000)$, perilaku seks berisiko $(p=0,002)$, dan penggunaan narkoba suntik $(p=0,569)$.

Kesimpulan: Terdapat hubungan yang signifikan antara penggunaan kondom dan perilaku seks berisiko dengan kejadian HIV pada LSL. Sedangkan riwayat IMS, dan penggunaan narkoba suntik tidak mempunyai hubungan signifikan dengan kejadian HIV pada LSL. 
Saran: Bagi LSL diharapkan dapat meningkatkan konsistensi penggunaan kondom dan pelicin, baik yang digunakan untuk dirinya sendiri maupun pasangan atau pelanggannya, selalu rutin melakukan tes VCT dan tidak malas bahkan malu untuk memeriksakan diri kepelayanan kesehatan, juga berkontribusi aktif dalam upaya pencegahan penularan HIV\&AIDS

Kata Kunci: Faktor Risiko, HIV\&AIDS, LSL

\section{PENDAHULUAN}

HIV atau Human Immunodeficiency Virus adalah virus yang menyerang kekebalan tubuh manusia yang kemudian berdampak pada penurunan sistem kekebalan tubuh sehingga menimbulkan satu penyakit yang disebut AIDS. HIV menyerang sel-sel darah puth yang dimana sel-sel darah putih itu merupakan bagian dari sistem kekebalan tubuh yang berfungsi melindungi tubuh dari serangan penyakit (Depkes RI, 2014).

Berdasarkan data dari UNAIDS, total penderita yang ada di berbagai negara sebanyak 1,8 juta. Masih bersumber dari data tersebut, terdapat 36,9 juta masyarakat hidup bersama HIV dan AIDS pada tahun 2017. Kawasan Asia Pasifik menduduki peringkat ketiga sebagai wilayah dengan pengidap HIV dan AIDS terbanyak diseluruh dunia dengan total penderita sebanyak 5,2 juta jiwa. Indonesia menjadi salah satu negara yang termasuk dalam Kawasan Asia Pasifik, dan Indonesia menyumbang angka 620.000 dari total 5,2 juta jiwa di Asia Pasifik yang terjangkit HIVIAIDS. Jika dikelompokkan berdasarkan latar belakangnya, penderita HIVIAIDS datang dari kalangan pekerja seks komersial (5,3\%), homoseksual $(25,8 \%)$, pengguna narkoba suntik $(28,76 \%)$, transgender $(24,8 \%)$, dan mereka yang ada ditahanan $(2,6 \%)$ (Kemenkes, 2018).

Pada laporan perkembangan HIV-AIDS dan PIMS di Indonesia Triwulan IV Tahun 2017. Dari bulan Oktober sampai dengan Desember 2017 jumlah orang yang terinfeksi HIV yang dilaporkan sebanyak 14.640 orang. Presentasi infeksi HIV tertinggi dilaporkan pada kelompok umur 24-29 tahun $(69,2 \%)$, diikuti kelompok umur 20-24 tahun $(16,7 \%)$, dan kelompok umur $\geq 50$ tahun $(7,6 \%)$. Rasio HIV antara laki-laki dan perempuan adalah 2:1. Presentase faktor risiko penularan HIV tertinggi pada bulan Oktober-Desember 2017 adalah hubungan seks berisiko pada heteroseksual $(22 \%)$, homoseksual $(21 \%)$, dan penggunaan alat suntik tidak steril pada penasun (2\%) (Kemenkes, 2018).

Menurut Kementrian Kesehatan RI menyebutkan bahwa jumlah kasus HIV di Indonesia menurut faktor risiko menunjukkan bahwa LSL menyumbang sabanyak 11.630 kasus dari 48.300 kasus jumlah infeksi HIV yang dilaporkan sampai dengan Desember 2017 (Kemenkes RI, 2018).

Khusus pada populasi LSL, prevalensi HIV cukup tinggi di wilayah urban perkotaan di Indonesia termasuk kota Bandar Lampung, Provinsi Lampung. Masalah HIV dan AIDS di Provinsi Lampung juga tidak dapat diabaikan. Jumlah kasus HIV dan AIDS yang dilapokan dari seluruh Kabupaten/ Kota di Provinsi Lampung terus meningkat dari tahun ke tahun. Berdasarkan data dan informasi profil Kesehatan RI 2017 jumlah penderita HIV yang dilaporkan di Lampung dari tahun 2015-2017 sebanyak 345 orang di tahun 2015, 381 orang ditahun 2016, dan 393 orang di tahun 2017 yang berarti mengalami peningkatan 1,48\% (Kemenkes RI, 2017). Dilihat dari kasus HIV di sebaran kabupaten dan kota di Lampung, kota Bandar Lampung yang merupakan pusat kota provinsi merupakan daerah dengan angka HIV tertinggi di Lampung. Dalam Profil Kesehatan Provinsi Lampung tahun 2016 mencatat penderita HIV di Kota Bandar Lampung sebanyak 312 orang, dan 28,52\% merupakan LSL (Dinkes Provinsi Lampung, 2016).

Perilaku membeli seks dalam satu tahun terakhir paling banyak dilakukan oleh waria sebanyak $26 \%$, penasun $19 \%$, dan LSL yang kemudian dikategorikan menjadi LSL risiko tinggi dan LSL risiko rendah (18\% dan 6\%). Dilihat dari perilaku menjual seks, $19 \%$ penasun dan $81 \%$ waria menjual seks pada laki-laki. Dan diantara $49 \%$ LSL yang menjual seks, $79 \%$ menjual seks pada laki-laki saja, 4\% pada perempuan saja, dan $17 \%$ pada laki-laki dan wanita (Kemenkes RI, 2011). Perilaku anal seks pada kelompok LSL sebagian besar dilakukan tanpa menggunakan kondom dilihat dari rendahnya penggunaan kondom (risiko tinggi $54 \%$ dan risiko rendah $60 \%$ ) pada hubungan seks terakhir dengan pasangan tidak tetap, dan pemakaian kondom dengan laki-laki pekerja seks sebesar 62\% (Kemenkes RI, 2014).

Penelitian yang dilakukan sebelumnya oleh Sidjabat et al. (2017) menunjukkan bahwa terdapat perbedaan perilaku hubungan seksual diantara kelompok kasus dan kontrol yaitu responden pada kelompok kasus $63,0 \%$ berhubungan seksual dengan risiko tinggi dan $25,9 \%$ responden pada 
kelompok kontrol yang berhubungan seksual dengan risiko tinggi. Pada distribusi responden menurut perilaku seksual berupa responden yang memakai obat gairah sebanyak $(7,4 \%)$ dengan tujuan agar mencapai orgasme berkali-kali, melakukan seks grup (18,5\%) dengan jumlah 3 orang $(9,3 \%), 4-5$ orang $(8,3 \%)$ dan $>10$ orang $(0,9 \%)$, menggunakan alat seks $(14,8 \%)$, melakukan kekerasan seksual $(11,1 \%)$, mendapatkan kekerasan seksual $(7,4 \%)$. Responden pada kelompok kasus dan kontrol yang tidak menggunakan kondom masing-masing sebanyak $63,0 \%$ dan 33,3\%. Hal tersebut menyatakan ada hubungan antara konsistensi penggunaan kondom dengan kejadian HIV.

Studi pendahuluan yang dilakukan pada komunitas LSL, dari 106 orang sebanyak 27 orang positif terinfeksi HIV dan 18 orang diantaranya masih aktif dalam komersialisasi seks, mereka dapat ditemui dibeberapa hotspot "Pasar Tengah" dimana LSL dari berbagai wilayah kabupaten/kota Lampung biasa berkumpul dan melakukan jual beli seks, dan sebagian besar mengatakan tidak konsistensi dalam penggunaan kondom tergantung dari permintaan pelanggan.

\section{METODOLOGI PENELITIAN}

Penelitian ini merupakan jenis penelitian analitik dengan pendekatan cross sectional. Populasi dalam penelitian ini berjumlah 106 laki-laki yang berhubungan seks dengan laki-laki lain (termasuk waria) minimal satu kali. Responden penelitian ini merupakan bagian dari komunitas LSL yang bersifat terbuka. Penelitian ini dilakukan di kawasan para Lelaki Seks Lelaki (LSL) berkumpul "Pasar Tengah" Kota Bandar Lampung bekerja sama dengan komunitas LSL dan LSL yang bersifat terbuka di Kota Bandar Lampung yang dilakukan pada bulan April - Juli tahun 2019. Teknik sampling yang digunakan adalah random sampling. Sampel dalam penelitian ini berjumlah 84 responden. Penelitian ini menggunakan uji Chi Square. Instrument yang digunakan dalam penelitian ini adalah Kuisioner ini telah diuji validitas dan reliabilitasnya.

\section{HASIL DAN PEMBAHASAN}

Analisis Univariat

Tabel 1.

Distribusi frekuensi faktor Resiko Kejadian HIV pada LSL

\begin{tabular}{lcc}
\hline \multicolumn{1}{c}{ Variabel } & Frekuensi & Persentase \\
\hline Kejadian HIV & & \\
Ya & 22 & 26,2 \\
Tidak & 62 & 73,8 \\
Penggunaan kondom & & \\
Ya & 45 & 53,6 \\
Tidak & 39 & 46,4 \\
Riwayat IMS & & \\
Ya & 19 & 22,6 \\
Tidak & 65 & 77,4 \\
Perilaku seks berisiko & & \\
Berisiko tinggi & 53 & 63,1 \\
Berisiko rendah & 31 & 36,9 \\
Penggunaan narkoba suntik & & \\
Ya & 4 & 4,8 \\
Tidak & 80 & 95,2 \\
\hline
\end{tabular}

Dalam penelitian Firdaus dan Agustin (2012) menyebutkan bahwa dari 621 LSL yang menjadi mitra Yayasan Lentera Minangkabau Sumatera Barat, terdapat 24 LSL yang teridentifikasi terinfeksi HIV berdasarkan diagnosis dokter di RSUP. DR. M. Djamil Padang. Sedangakan penelitian Mardaniah (2018), dari 42 reponden terdapat 20 reponden (46.7\%) positif HIV dan AIDS, dan 20 responden $(52,4 \%)$ negative HIV dan AIDS.

Hasil yang didapatkan oleh peneliti dan dua peneliti sebelumnya menunjukkan bahwa sebagian besar tidak terinfeksi HIV. Menurut peneliti hasil ini mungkin tidak sesuai dengan kenyataan karena sebagian besar LSL yang menjadi responden mengaku tidak mau melakukan pemeriksaan VCT, 
sedangkan akses untuk mendapatkan pelayanan kesehatan sangatlah mudah. Dan komunitas sudah banyak melalukan penyuluhan terkait, tetapi masih banyak LSL yang kesadaran akan kesehatannya kurang. LSL akan melakukan pemeriksaan saat mengalami gejala infeksi oportunistik seperti infeksi pneumonia karena menurut LSL, seseorang yang terinfeksi pneumonia dipastikan terinfeksi HIV tetapi tidak semua yang terinfeksi HIV mengalami infeksi pneumonia. Anggapan salah itulah yang menjadikan banyak kasus HIV pada LSL yang tidak teridentifikasi dan dilaporkan, inilah mengapa disebut fenomena gunung es pada kejadian HIV. Pemeriksaan VCT secara rutin sangat penting karena LSL melakukan seks berisiko yang dapat menyebabkan penularan HIV semakin cepat.

\section{Analisis Bivariat}

Tabel 2.

Hubungan Faktor Resiko dengan Kejadian HIV pada LSL

\begin{tabular}{|c|c|c|c|c|c|c|c|}
\hline \multirow{3}{*}{ Variabel } & \multicolumn{6}{|c|}{ Kejadian HIV } & \multirow{3}{*}{$\begin{array}{c}p \\
\text { value }\end{array}$} \\
\hline & \multicolumn{2}{|c|}{$\mathrm{Ya}$} & \multicolumn{2}{|c|}{ Tidak } & \multicolumn{2}{|c|}{ Total } & \\
\hline & $\mathrm{n}$ & $\%$ & $\mathrm{~N}$ & $\%$ & $\mathrm{n}$ & $\%$ & \\
\hline \multicolumn{8}{|l|}{ Penggunaan kondom } \\
\hline $\mathrm{Ya}$ & 15 & 11,1 & 40 & 88,9 & 45 & 100 & \multirow{3}{*}{0,001} \\
\hline Tidak & 17 & 43,6 & 22 & 56,4 & 39 & 100 & \\
\hline \multicolumn{7}{|l|}{ Riwayat IMS } & \\
\hline $\mathrm{Ya}$ & 5 & 26,3 & 14 & 73,7 & 19 & 100 & \multirow{2}{*}{1,000} \\
\hline Tidak & 17 & 26,2 & 48 & 73,8 & 65 & 100 & \\
\hline \multicolumn{8}{|l|}{ Perilaku seks berisiko } \\
\hline Berisiko tinggi & 20 & 37,7 & 33 & 62,3 & 53 & 100 & \multirow{3}{*}{0,002} \\
\hline Berisiko rendah & 2 & 6,5 & 29 & 93,5 & 31 & 100 & \\
\hline \multicolumn{7}{|c|}{ Penggunaan narkoba suntik } & \\
\hline $\mathrm{Ya}$ & 0 & 0 & 4 & 100 & 4 & 100 & \multirow{2}{*}{0,569} \\
\hline Tidak & 22 & 27,5 & 58 & 72,5 & 80 & 100 & \\
\hline
\end{tabular}

Dari 22 responden yang terinfeksi HIV, terdapat 5 responden $(11,1 \%)$ menggunakan kondom, pernah mengalami riwayat IMS sebanyak 5 responden (26,3\%), 20 responden $(37,7 \%)$ perilaku seks berisiko tinggi, dan seluruh responden yang terinfeksi HIV tidak ada yang menggunakan narkoba suntik. Variabel yang tidak mempunyai hubungan signifikan dengan kejadian HIV pada LSL yaitu riwayat IMS $(p=1,000)$ dan penggunaan narkoba suntik $(p=0,569)$. Variabel yang mempunyai hubungan signifikan dengan kejadian HIV pada LSL yaitu penggunaan kondom ( $p=$ $0,001)$ dan perilaku seks berisiko $(p=0,002)$.

\section{Hubungan penggunaan kondom dengan kejadian HIV pada LSL}

Dari hasil uji chi-square pada $(\alpha) 0,05$ didapatkan nilai $p=0,001$, yang berarti lebih besar dari $(\alpha)$ sehingga Ho ditolak yang artinya ada hubungan antara penggunaan kondom dengan kejadian HIV pada LSL. Penggunaan kondom dalam penelitian ini dibagi dalam 2 kategori, yaitu ya dan tidak. Penggunaan kondom dikategorikan ya apabila LSL tersebut selalu menggunakan kondom setiap melakukan hubungan seksual. Penggunaan kondom pada LSL dikategorikan tidak apabila responden tidak pernah dan kadang-kadang menggunakan kondom setiap melakukan hubungan seksual. Dari 22 responden yang terinfeksi HIV, 5 responden (22,72\%) dikategorikan ya menggunakan kondom, 2 responden (9,1\%) dikategorikan tidak menggunakan kondom dan sisanya 15 responden $(68,18 \%)$ dikategorikan tidak "kadang-kadang" menggunakan kondom setiap melakukan hubungan seksual.

Dalam berhubungan seksual akan terjadi perlukaan pada jaringan sehingga melalui luka tersebut virus dapat masuk dan menginfeksi tubuh. Untuk itu sangat penting pemakaian kondom secara konsistensi, kondom jika penggunaannya konsistensi dan benar dapat menurunkan risiko penularan HIV, termasuk penularan penyakit melalui sekresi genital. Hanya saja jika penggunaan kondom konsistensi namun tidak benar dan tidak hygiene dapat menyebabkan bertambahnya risiko (Cempaka dan Kardiwinata, 2012).

Penggunaan kondom saat melakukan hubungan seksual merupakan salah satu program pencegahan penularan HIV \& AIDS di Indonesia, dan hal tersebut masih belum kelihatan efektif 
terhadap para pelanggan PSK, PSK, gay, dan waria. Beberapa kendala dalam pencegahan HIV\&AIDS ini adalah belum adanya kebijakan tentang kewajiban penggunaan kondom di lokalisasi, serta adanya keterbatasan promosi kesehatan tentang penggunaan kondom kepada masyarakat, terutama kelompok berisiko.

Menurut hasil penelitian Ratnawati (2002) dalam Hartono (2009), penggunaan kondom pada gay yang sudah tinggi juga harus didukung dengan penggunaan kondom secara konsistensi. Penggunaan kondom secara konsistensi pada gay sangat sedikit. Hasil penelitian Kwong et al, (2011) menunjukkan $43 \%$ pria yang sering melakukan seksual secara anal sama sekali tidak pernah menggunakan kondom, ini karena mereka mengira pasangan seksual mereka sehat dan bebas dari penyakit.

Selain itu, dalam hasil perilaku populasi paling berisiko dan kepuasan layanan Bali yang dilakukan oleh KPA tahun 2010, dari 266 gay yang menggunakan kondom secara konsistensi baru sebanyak 97 orang (36\%) padahal penggunaan kondom merupakan salah satu cara pencegahan (Cempaka dan Kardiwinata, 2012).

Hasil penelitian ini sejalan dengan hasil penelitian Ramadhani et al (2013), menyatakan ada hubungannya antara penggunaan kondom dengan kejadian HIV dengan hasil $p$ value $=0,001$, yaitu terdapat $92,3 \%$ wilayah dengan penggunaan kondom yang tergolong tinggi berstatus endemis dan sebesar $81,8 \%$ wilayah dengan penggunaan kondom yang tergolong rendah berstatus nonendemis.

Hal ini menurut peneliti yang paling penting selain penggunaan kondom tetapi juga konsistensi pada penggunaan kondom tersebut. Tidak konsisten dalam penggunaan kondom pun menurut peneliti dipengaruhi oleh pengalaman dan pengetahun responden berdasarkan hasil wawancara mendalam yang dilakukan juga oleh peneliti. Salah satu responden mengatakan melakukan hubungan seksual sesama jenis sejak kelas 2 SMP dan saat itu belum sama sekali terpapar informasi apapun terkait dengan dampakdampak dari perilaku seksual itu artinya saat melakukan itu sampai di tahun 2004 (kelas 2 SMA) tidak pernah menggunakan kondom, dan menggunakan kondom setelah mendapatkan informasi terkait dampak dari peilaku hubungan seksual sesama jenis. Responden lainnya mengatakan bahwa penggunaan kondom sesuai dengan peran mereka saat melakukan hubungan seksual. Jika peran mereka sebagai top maka menggunakan kondom, sebaliknya jika peran mereka hanya sebagai bottom maka tidak menggunakan kondom.

\section{Hubungan riwayat IMS dengan kejadian HIV pada LSL}

Berdasarkan hasil statistik, menunjukkan bahwa uji $p$ value $=1,000(p \geq 0,05)$ yang berarti tidak ada hubungan yang bermakna antara riwayat IMS dengan kejadian HIV pada LSL. Dari 19 responden yang mengatakan pernah mengalami riwayat IMS 2 responden (10,5\%) mengalami klamidia, 2 responden $(10,5 \%)$ dengan herpes genetalia, terbanyak pernah mengalami gonore yaitu 12 responden $(63,2 \%)$, sifilis sebanyak 1 reponden $(5,3 \%)$, dan 2 responden $(10,5 \%)$ pernah mengalami trikomoniasis. Sedangkan dari 5 responden yang terinfeksi HIV, $80 \%$ mengalami gonore sisanya 20\% mengalami herpes genetalia.

Infeksi Menular Seksual (IMS) adalah penyakit yang penularan utamanya melalui hubungan seksual. Cara hubungan seksual tidak hanya terbatas secara genito-genital (kelamin ke kelamin) saja, tetapi dapat juga secara oro-genital (mulu ke kelamin), atau secara ano-genital (kelamin ke dubur). IMS merupakan pintu masuk bagi penularan HIV karena adanya cairan tubuh atau darah pada luka akibat IMS. Seseorang yang telah terinfeksi IMS dan menginfeksi uretra, rectum, atau faring dapat meningkatkan risiko infeksi HIV jika belum terinfeksi HIV, dan pada orang yang telah terinfeksi HIV akan memudahkan penularan HIV kepada orang lain (Condoms, 2012). .

Penyakit Gonore atau biasa dikenal dengan kencing nanah dalam arti luas mencakup semua penyakit yang disebabkan oleh Neisseria gonorrhoeae. Gejalanya seperti penis mengeluarkan cairan seperti nanah berwarna putih kekuningan atau kehijauan, rasa terbakar saat buang air kecil, rasa terbakar di tenggorokkan biasanyan karena oral seks, testis terasa nyeri atau bengkak, pembengkakan kelenjar gerah bening.

Menurut Laksana \& Lestari (2010) peradangan dan ulkus pada penderita IMS meningkatkan kerentanan terhadap infeksi HIV, karena rusaknya barrier mucosal memudahkan masuknya virus HIV ke dalam pembuluh darah.

Menurut peneliti yang menyebabkan penyebaran HIV berdasarkan riwayat IMS melonjak tinggi karena seseorang yang memiliki IMS tidak akan memberitahu secara langsung kepada partner seks mereka. Dari hasil wawancara mendalam yang dilakukan peneliti, responden mengatakan bahwa mereka memeriksakan diri ke palayanan kesehatan setelah timbul gejala. Sebelum timbulnya gejala mereka tidak pernah memeriksakan diri ke 
palayanan kesehatan dan menganggap bahwa diri mereka sehat. Responden lainnya mengatakan tidak pernah memeriksakan diri ke dokter dikarenakan rasa malu untuk menceritakan atau berkonsultasi terkait dengan gejalan IMS yang mereka rasakan.

\section{Hubungan perilaku seks berisiko dengan kejadian HIV pada LSL}

Analisa hasil uji chi square didapatkan $p$ value $=0,002(p \leq 0,05)$ sehingga Ho ditolak, artinya ada hubungan antara perilaku seks berisiko terhadap kejadian HIV pada LSL. Seks anal merupakan aktivitas seksual yang dilakukan LSL untuk mencapai kepuasan seksualnya dan sangat berbahaya karena anus mengandung banyak bakteri sumber penyakit.

Hasil penelitian ini sejalan dengan penelitian Firdaus \& Agustin (2012), menunjukkan ada hubungan yang signifikan antara perilaku seks berisiko dengan kejadian HIV ( $p=0,009$ ). LSL cenderung memiliki banyak pasangan seks, berganti-ganti pasangan dalam berhubungan seks dan banyak diantara LSL juga membeli dan menjual seks. Selain itu, perilaku penggunaan kondom dan pelumas masih rendah. Bila kondisi seperti ini tidak segera tertangani, maka dikhawatirkan penularan HIV tidak hanya terkonsentrasi pada populasi kunci saja melainkan akan dengan cepat menyebar secara luas ke masyarakat. Perilaku seks berisiko tentunya terkait dengan kurangnya pengetahuan yang dimiliki oleh komunitas LSL mengenai bahaya yang dapat ditimbulkannya. Adanya stigma dikhawatirkan membuat orang dengan HIV dan AIDS (ODHA) akan lebih tertutup sehingga sulit untuk diberikan upaya kesehatan. Selain itu, dikhawatirkan akan muncul perasaan dendam di kalangan ODHA sehingga berusaha menularkan HIV kepada masyarakat umum.

Hasil penelitian Hartono (2009) menjelaskan bahwa terdapat hubungan antara perilaku seksual dengan kejadian PMS pada komunitas Gay mitra PKBI Yogyakarta dengan $(p=$ 0,009 ) dan $\mathrm{OR}=9.767$. Di Amerika kira-kira 91\% diantara LSL yang berusia 13-19 tahun, didiagnosa terinfeksi HIV\&AIDS melalui kontak seks lelaki dengan lelaki.

Pria dengan peran reseptif memiliki risiko lebih besar terinfeksi HIV\&AIDS dibanding yang berperan insertif. Dari hasil wawancara responden mengatakan saat berperan menjadi top mereka melakukan anal dan oral seks. Terkadang mereka memasukkan satu atau dua jari kedalam anus pasangan yang berperan menjadi bottom. Peran ini tidak terkhususkan tergantung dari kesepakatan dengan pasangan. Respoden lainnya mengatakan tidak harus melakukan penetrasi tetapi sesekali mereka menjilati anus pasangan atau hanya sekedar menggesekkan alat kelamin pasangan di antara kedua paha mereka untuk mendapatkan sensasi dan mencapai kenikmatan.

Hal ini yang menurut peneliti meningkatkan penularan HIV, karena anus tidak didesain untuk berhubungan seksual sehingga akan mengalami perlukaan saat melakukan anal seks dan memudahkan masuknya virus HIV. Apalagi anus kaya akan sel CD4 yang merupakan target utama dari virus HIV. Selain itu, anus tidak seperti vagina pada wanita yang dapat melumasi saat merasa terangsang sehingga mudah sekali untuk mengalami perlukaan.

\section{Hubungan penggunaan narkoba suntik dengan kejadian HIV pada LSL}

Berdasarkan hasil statistik, menunjukkan bahwa uji $p$ value $=0,569(p \geq 0,05)$ yang berarti tidak ada hubungan yang bermakna antara penggunaan narkoba suntik dengan kejadian HIV pada LSL. Dari 84 responden, terdapat 11 responden $(13,1 \%)$ menggunakan narkotika, dan dari 11 responden sebanyak 4 responden $(36,4 \%)$ menggunakan narkoba suntik. 1 responden yang menggunakan narkoba suntik melakukan berbagi jarum suntik dengan pengguna narkoba lainnya.

Narkoba parenteral adalah semua jenis narkoba yang digunakan dengan cara disuntikkan pada saluran intravena. Narkoba parenteral juga merupakan faktor risiko penularan HIV\&AIDS. Pengguna narkoba suntik sangat rentan tertular HIV\&AIDS karena alat suntik sering digunakan secara bergantian. Menurut UNAIDS, $10 \%$ infeksi HIV di dunia didapat melalui jarum atau peralatan jarum suntik.

Penggunaan jarum suntik secara bergantian adalah risiko tinggi dari penyakit fisik melalui darah diantaranya HIV, suntikkan intravena pada pengguna jarum suntik dan digunakan secara bergantian secara tidak sadar telah memasukkan virus ke dalam darah (Sumiati, et al 2009).

Hasil penelitian ini sejalan dengan penelitian yang dilakukan Firdaus \& Agustin (2013) menunjukkan tidak ada hubungan yang signifikan antara penggunaan kondom dengan kejadian HIV pada komunitas LSL nilai $(p=1.000)$.

Menurut peneliti meskipun hasil penelitian menunjukkan tidak ada hubungan antara kejadian HIV dengan penggunaan narkoba suntik, namun jika dilihat dari data penelitian ditemukan bahwa ada LSL berbagi jarum suntik bersama. Hal ini menandakan meskipun tingkat penggunaan jarum 
suntik rendah pada komunitas LSL, namun mereka cendrung berbagi jarum suntik dengan pengguna narkoba lainnya sehingga penularan HIV bisa berasal dari luar komunitas LSL atau sebaliknya.

\section{KESIMPULAN}

Berdasarkan hasil penelitian yang dilakukan di hotspot pasar tengah Kota Bandar Lampung mengenai analisis faktor risiko kejadian HIV pada LSL tahun 2019 dapat disimpukan bahwa $26,2 \%$ responden terinfeksi HIV, 53,6\% menggunakan kondom, $77,4 \%$ tidak mempunyai riwayat IMS, $63,1 \%$ berperilaku seks berisiko tinggi, dan $4,8 \%$ menggunakan narkoba suntik. Variabel yang tidak mempunyai hubungan signifikan dengan kejadian HIV pada LSL yaitu riwayat IMS dan penggunaan narkoba suntik. Variabel yang mempunyai hubungan signifikan dengan kejadian HIV pada LSL yaitu penggunaan kondom dan perilaku seks berisiko.

\section{SARAN}

Bagi LSL diharapkan dapat meningkatkan konsistensi penggunaan kondom dan pelicin, baik yang digunakan untuk dirinya sendiri maupun pasangan atau pelanggannya, selalu rutin melakukan tes VCT dan tidak malas bahkan malu untuk memeriksakan diri kepelayanan kesehatan, juga berkontribusi aktif dalam upaya pencegahan penularan HIV\&AIDS. Bagi Komunitas LSL pendamping diharapkan dapat memperluas intervensi tentang bahaya serta upaya pencegahan penularan HIV dan AIDS melalui media-media KIE (Komunikasi, Informasi, dan Edukasi) di hotspothotspot (tempat berkumpul) ataupun diduga hotspot LSL.

\section{DAFTAR PUSTAKA}

Cempaka, P., \& Kardiwinata, P. (2012). POLA HUBUNGAN SEKSUAL DAN RIWAYAT IMS PADA GAY DI BALI. ARCHIVE OF COMMUNITY HEALTH, 1(2), 84-89.

Condoms, C. D. C. (2012). STDs: fact sheet for public health personnel.

Depkes RI. (2014). Pedoman Penatalaksanaan Infeksi Menular Seksual, Jakarta: Dirjen PPM\&PL.

Dinas Kesehatan Provinsi Lampung. (2016). Profil Kesehatan Provinsi Lampung Tahun 2016, Lampung: Dinas Kesehatan Provinsi Lampung.
Firdaus, S., \& Agustin, H. (2013). Faktor Risiko Kejadian HIV pada Komunitas LSL (Lelaki Seks dengan Lelaki) Mitra Yayasan Lantera Minangkabau Sumatera Barat. Jurnal Kesehatan Komunitas, 2(2), 94-99. https://doi.org/10.25311/jkk.vol2.iss2.52

Hartono, A. (2009). Faktor Risiko Kejadian Penyakit Menular Seksual (Pms) Pada Komunitas Gay Mitra Strategis Perkumpulan Keluarga Berencana Indonesia (Pkbi) Yogyakarta (Doctoral dissertation, Universitas Muhammadiyah Surakarta).

Kemenkes RI. (2018). Laporan Kasus HIV dan AIDS Indonesia, Jakarta: Kemenkes RI.

Kemenkes RI. (2017). Profil Kesehatan Indonesia, Jakarta: Depkes RI.

Kemenkes RI. (2014). Statistik Kasus HIVIAIDS di Indonesia s/d September 2014, Jakarta: Kemenkes RI.

Kemenkes RI. (2018). Strategi Komunikasi Penanggulangan HIV dan AIDS di Indonesia, Jakarta: Direktorat Jendral P2PL Kemenkes RI.

Kementrian Kesehatan R.I.(2011). Surveilans Terpadu Biologis dan Perilaku 2011, Jakarta: Kemenkes RI.

Laksana, A. S. D., \& Lestari, D. W. D. (2010). Faktor-faktor risiko penularan HIVIAIDS pada laki-laki dengan orientasi seks heteroseksual dan homoseksual di Purwokerto. Mandala of Health, 4(2), 113123.

Kwong-Lai Poon, M., Pui-Hing Wong, J., Sutdhibhasilp, N., Ho, P. T. T., \& Wong, B. (2011). Condom use among East and Southeast Asian men attending a gay bathhouse in Toronto. Canadian Journal of Human Sexuality, 20(3).

Ramadhani, H. H., Aminudin, R., Bahar, B. (2013). Pemetaan dan Faktor yang Berhubungan dengan Kejadian HIV\&AIDS di Provinsi Sulawesi Selatan, Jurnal Masyarakat Epidemiologi Indonesia. 2(2), 98-102.

Sidjabat, F. N., Setyawan, H., Sofro, M. A., \& Hadisaputro, S. (2017). LELAKI SEKS LELAKI, HIVIAIDS DAN AKTIVITAS SEKSUALNYA DI SEMARANG. Jurnal Kesehatan Reproduksi, 8(2), 131-142.

Sumiati, D., Nurhaeni, H., \& Aryani, R. (2009). Kesehatan jiwa remaja dan konseling. Jakarta: Trans Info Media, 8892. 